\title{
鋼中炭化モリブデン $\left(\mathrm{Mo}_{2} \mathrm{C}\right)$ 抽出分離定量法*
}

\author{
神森大彦**田口勇** 小野昭紘**
}

Ôhiko Kammori, Isamu Taguchi and Akihiro Ono: Quantitative Extraction of Molybdenum Carbide $\left(\mathrm{Mo}_{2} \mathrm{C}\right)$ from Steel. Potentiostatic electrolysis with $\mathrm{Na}$-citrate- $\mathrm{KBr}$-electrolyte, potentiostatic electrolysis with $\mathrm{FeCl}_{3}-\mathrm{ZnCl}_{2}$-acetylacetone-electrolyte, direct extraction with acetylacetone, $\mathrm{I}_{2}$-n-butylalcohol extraction, $\mathrm{FeCl}_{3}-\mathrm{n}$-butylalcohol extraction and acid extraction were studied for the isolation of $0.02 \sim 1 \%$ of molybdenum carbide $\left(\mathrm{Mo}_{2} \mathrm{C}\right)$ from $\mathrm{Fe}-\mathrm{Mo}-\mathrm{C}$ steels tempered at $650^{\circ} \sim 750^{\circ} \mathrm{C}$ for $1 \mathrm{hr}$. Molybdenum carbide $\left(\mathrm{Mo}_{2} \mathrm{C}\right)$ extracted from the steels was found to be unstable in water. The highest value and the best precision were achieved when the steels were extracted at room temperature with $30 \mathrm{~N}$ phosphoric acid. The following method was recommended for the quantitative extraction of molybdenum carbide $\left(\mathrm{Mo}_{2} \mathrm{C}\right)$.

One-tenth $\mathrm{g}$ of chipped sample is dissolved at room temperature with $50 \mathrm{~mL}$ of $30 \mathrm{~N}$ phosphoric acid. The extracted residue is collected through the Millipore filter $(220 \mathrm{~m} \mu)$ and washed by $30 \mathrm{~N}$ phosphoric acid. Molybdenum in the residue is determined by MIBK-extraction-thiocyanide-spectrophotometry and molybdenum carbide $\left(\mathrm{Mo}_{2} \mathrm{C}\right)$ is calculated.

The time required for the extraction was $15 \sim 25 \mathrm{hrs}$ and the time for molybdenum determination was about $1 \mathrm{hr}$.

(Received August 14, 1967)

\section{I. 緒言}

鋼中析出物介在物の研究が進むにつれて, より正確な分 析法が要求されるようになつたので一連の研究を企画し た。析出物介在物分析法の研究は一般の元素分析法の研究 と異なり，標準試料がなく，かつ対象が複雑すぎるなどの 理由で非常に困難である，そこで著者らはまず比較的単純 な系の試験溶解鋼を対象として検討を行ならことにした。 本報はその第 1 報で, 鋼中の炭化モリブデン $\left(\mathrm{Mo}_{2} \mathrm{C}\right)$ の抽 出分離定量法について述べる。これまで鋼からモリブデン を含を析出物を抽出分離した報告は多い(1) 〜 (5) が定量法に ついて詳細に検討した報告は見あたらない，炭化モリブデ ン $\left(\mathrm{Mo}_{2} \mathrm{C}\right)$ は鋼中では準安定に存在する炭化物で, 長時間 の焼もどしでは $\mathrm{M}_{6} \mathrm{C}$ として安定化する ${ }^{(6)}$ と考兄られて拉 り, その分析化学的性質も Kopylova ${ }^{(7)}$ が酸, アルカリに ついて調べた結果では炭化タンタル $(\mathrm{TaC})$, 炭化ニオブ $(\mathrm{NbC})$, 炭化タングステン $\left(\mathrm{W}_{2} \mathrm{C}, \mathrm{WC}\right)$, 炭化チタン $(\mathrm{TiC})$, 炭化ジルコニウム $(\mathrm{ZrC})$, 炭化ハフニウム $(\mathrm{HfC})$ 上り 子不 安定である. 成田の総説 ${ }^{(8)}$ とよれば炭化モリブデン $\left(\mathrm{Mo}_{2} \mathrm{C}\right)$

** 八幡製鉄株式会社東京研究所 (Tokyo Research Institute of Yawata Iron and Steel Co., Ltd., Kawasaki)

* 1967 年 4 月本会東京大会飞発表 ; 鋼中析出物介在 物分析法の研究 (第 1 報)

（1）佐藤, 西沢, 玉置: 本誌, 24 (1960), 395, 469.

(2) 佐藤, 西沢: 本誌, 24(1960), 473.

(3) K.A.Ridal and A.G.Quarrell : J.Iron Steel Inst., $200(1962), 359,366$.

(4) K.Kuo: J.Iron Steel Inst., 173(1953), 363.

(5) W.Koch: Metallkundliche Analyse, Verlag Stahleisen, Düsseldorf, (1965), 264.

(6) D. Raynor, J.A. Whiteman and R. W. K.Honeycombe: J.Iron Steel Inst., 204 (1966), 349.

(7) V. P. Kopylova: Zhur. Priklad. Khim., 34 (1961), 1936 ; C.A., $56(1962), 4344 \mathrm{f}$.

（8）成田：鉄之鋼，52(1966)，1098.
は水に不溶とあるが, “著者らの追試結果によれば市販合成 試料では不溶であるが，鋼から抽出分離した炭化モリブデ ン $\left(\mathrm{Mo}_{2} \mathrm{C}\right)$ は水にすら不安定であることがわかつた。この不 安定な炭化モリブデン $\left(\mathrm{Mo}_{2} \mathrm{C}\right)$ を鋼から抽出分離して定量 するために, クエン酸系電解液定電位電解法, アセチルア セトン系電解液定電位電解法, アセチルアセトン直接溶解 法 ${ }^{(9)}$, 上了素-ブチルアルコール溶解法, 塩化鉄-ブチルア ルコール溶解法などを検討したが電解液, 溶解液による炭 化モリブデン $\left(\mathrm{Mo}_{2} \mathrm{C}\right)$ の溶解が避けられなかつたり，分析 精度が不良であつたり, 問題点が多かつた。しかし, 高濃 度のりん酸を用いる酸溶解法を検討したところ, もつとも 高い抽出分離率が得られ，かつ分析精度も良好であつたの で抽出分離条件などを詳細に検討して定量法を確立した。 なお，この研究を発表したのちに金沢ら ${ }^{(10)} は \mathrm{Nb}-\mathrm{Mo}$ 調質 系 $80 \mathrm{~kg} / \mathrm{mm}^{2}$ 高張力鋼中の 析出物の挙動を調べるために 炭化モリブデン $\left(\mathrm{Mo}_{2} \mathrm{C}\right)$ の抽出分離法として塩酸 $(1+1)$ 室 温溶解法を選定した経過を報告したが，本報の結果と異な る.

\section{II. 装置, 試薬および試 料}

\section{1. 装置および試薬など}

(1) 東京光電製定電位電解装置 ANA-102 型

(2) 東京光電製万光板光電光度計 7 B 型

(3) Koch-Sundermann 式縦型電解槽

(4) 炭化モリブデン $\left(\mathrm{Mo}_{2} \mathrm{C}\right)$ 合成試料: Allis Chalmers 社 (米)製 325 ×ッシュ以下

(5) フィルター：ミリポアフィルター $(100,220,300$

（9）神森, 田口，滝本：日本分析化学会第 14 年会講演 $22 \mathrm{~A} 11,(1965)$.

（10）金沢, 中島, 岡本, 田辺, 中沢：本誌, 31 (1967), 171. 
$\mathrm{m} \mu)$ とせうフィルター(f)

（6）りん酸：昭和化学製，キシダ化学製，和光純薬製，

関東化学剩の特級 $(85 \%)$

\section{2. 試料}

笑験に用いた武料の熱処理条件と化学分析值を Table 1 に示す。これらの試料は昭和電工製電解鉄にモリブデン，
鎡中に和ける炭化モリブデン $\left(\mathrm{Mo}_{2} \mathrm{C}\right)$ の存在形態を検討 するために試料 $A$ を刘象として薄膜電影観察，抽出レプリ

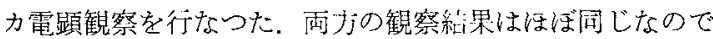
後者の結果の例老Photo.1，2 に示す．この試料中の炭化 物は炭化モリブデン $\left(\mathrm{Mo}_{2} \mathrm{C}\right)$ の文で $\mathrm{M}_{6} \mathrm{C}$ の存在は認められ なかつたが炭化モりブデン $\left(\mathrm{Mo}_{2} \mathrm{C}\right)$ には針状 (Photo.1) と粒

Table 1 Heat treatment and chemical composition of steel samples.

\begin{tabular}{|c|c|c|c|c|c|c|c|c|c|}
\hline \multirow{2}{*}{ Mark } & \multirow{2}{*}{ Heat treatment } & \multicolumn{8}{|c|}{ Chemical composition $(\%)$} \\
\hline & & C & Mo & $\mathrm{Si}$ & $\mathrm{Mn}$ & $\mathrm{P}$ & S & 0 & N \\
\hline$A$ & $\begin{array}{l}1200^{\circ} \mathrm{C} \times 2 \mathrm{hr} \rightarrow W . Q . \\
750^{\circ} \mathrm{C} \times 1 \mathrm{hr} \rightarrow W . \mathrm{Q} .\end{array}$ & 0.16 & 1.51 & 0.062 & $<0.01$ & 0.006 & 0.002 & $<0.001$ & 0.002 \\
\hline$B$ & $700^{\circ} \mathrm{C} \times 1 \mathrm{hr} \rightarrow \mathrm{A} . \mathrm{C}$ & 0.13 & 1.04 & 0.033 & $<0.01$ & 0.003 & 0.005 & $<0.001$ & 0.001 \\
\hline $\mathrm{C}$ & $\begin{array}{l}1200^{\circ} \mathrm{C} \times 2 \mathrm{hr} \rightarrow \mathrm{W} . \mathrm{Q} . \\
650^{\circ} \mathrm{C} \times 1 \mathrm{hr} \rightarrow \mathrm{A} . \mathrm{C} .\end{array}$ & 0.16 & 1.51 & 0.062 & $<0.01$ & 0.006 & 0.002 & $<0.001$ & 0.002 \\
\hline
\end{tabular}

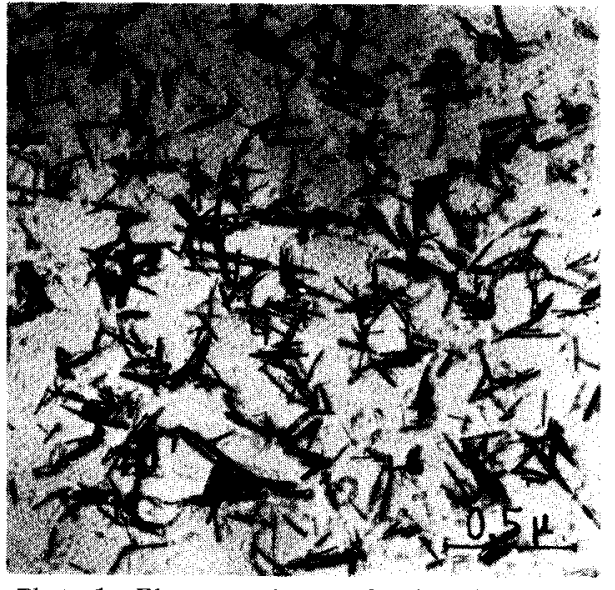

Photo.1 Electron micrograph of molybdenum carbide $\left(\mathrm{MO}_{2} \mathrm{C}\right)$ in extraction replica prepared from steel $A$ (No.I) .

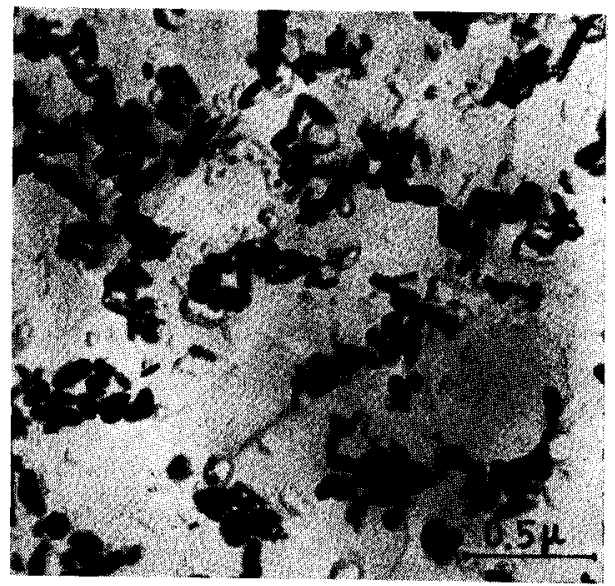

Photo.2 Electron micrograph of molybdenum carbide $\left(\mathrm{MO}_{2} \mathrm{C}\right)$ in extraction replica prepared from steel $A$ (No.2) .

炭素を添加して真空溶解で溶製した $10 \mathrm{~kg}$ 鎦境を $12 \mathrm{~mm}$ 厚に熱延し，蓺処理したものである.
状 (Photo.2)の 2 種があり，針状の長さは $500 \sim 2500 \AA$ ，楥

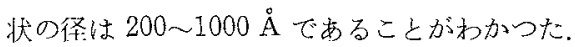

\section{III. 定 量 法 の 検 討}

1. 炭化モリブデン $\left(\mathrm{Mo}_{2} \mathrm{C}\right)$ の分析化 学 的 性 質

炭化モりブデン $\left(\mathrm{Mo}_{2} \mathrm{C}\right)$ は成四の総倣 ${ }^{(3)}$ に上れぱ水，アル カリに不溶，硝酸，フッ酸，熱酼酸，盐酸にわずかに溶け

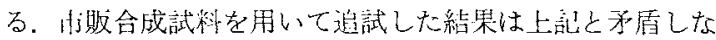

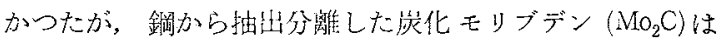
分析化学的に不安定であると子测されたのでつぎの检討を 行なつた。

(1) 水, アルコール,アセチルアセトンに 対する性啠

試料 $\mathrm{A}$ から硫酸 $(1+5)$ 加熱溶解法で抽出分離し，真空乾 燥した残さ(モりブデン含存率：70.2\%)の5 mgをそれぞ れ三觕フラスコ（容最 $200 \mathrm{~mL}$ ) にはかりとり，イオン交換

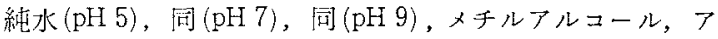
セチルアセトンの $50 \mathrm{~mL}$ を加えて 30 分間, 常温でマグネ ブィックスターラーを用いて攪挥したのら、ミリポフフィ ルター $(100 \mathrm{~m} \mu)$ で吸引渦し，万液中のモリブデンを娞 述の N の(2)の操作で定量して残さ中に換算した，結果に よればろ液中のモリブデン量は残さ中に撸算してイオン交 換純水(pH 5) の場合には24.7\%，同（pH 7) の場合には $32.2 \%$, 同 (pH 9) の場合には $43.5 \%$ ，メチルアルコール の場合には $8.6 \%$ ，アセチルアセトンの場合には $1.7 \%$ で あつた。以上からアセチルアセトン以外のイオン交換純

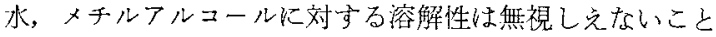
がわからた，水要るいはメチルアルコールを用いた場合に は炭化モリブデン $\left(\mathrm{Mo}_{2} \mathrm{C}\right)$ が溶解して青色を堡するので肉 眼観察でも溶解性は明らかである。

（2）抽出レプリカ電顕観察による水溶性 の検 討 
試料Aをバフ研摩し，飽和ピクラールに約 2 分間つけ, 試料面に酢酸メチルを分散させ，アセチルセルロースフィ ルムをはりつける，数分間放置したのちはく離し，カーボ ン蒸着し, 酢酸メチルでフィルムを溶解する。このカーボ ン膜を水中に一定時間つけたのち電顕観察を行なつた。電 顕観察の結果はPhoto.3, 4 に示すと抢りで，水につける

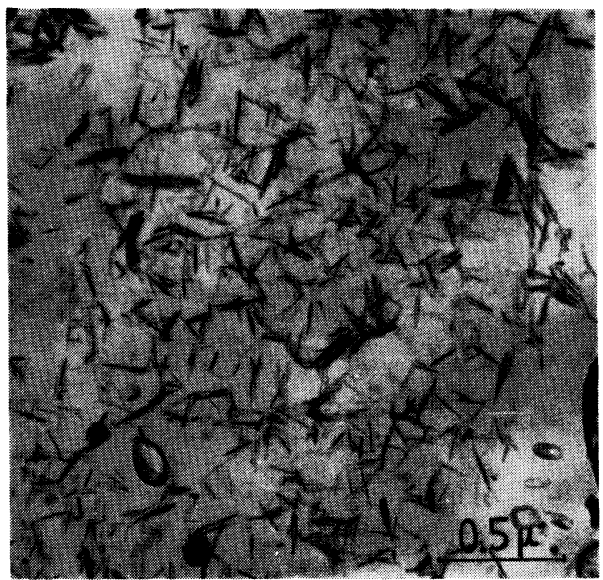

Photo.3 Electron micrograph of molybdenum carbide $\left(\mathrm{Mo}_{2} \mathrm{C}\right)$ in extraction replica prepared from steel A after treated with water for $1 \mathrm{hr}$.

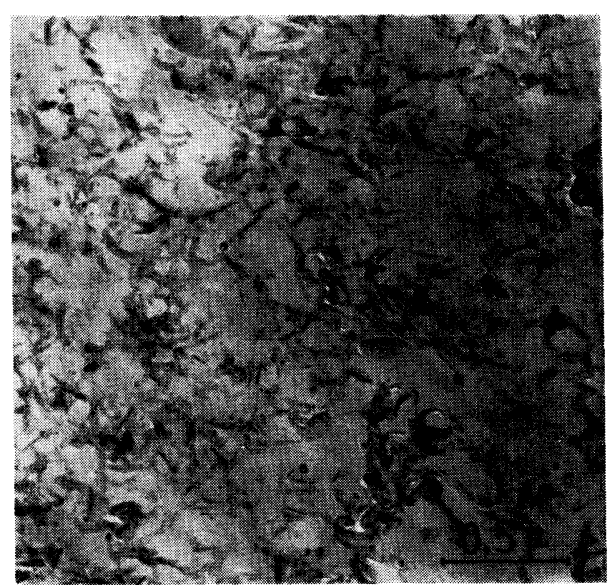

Photo.4 Electron micrograph of molybdenum carbide $\left(\mathrm{Mo}_{2} \mathrm{C}\right)$ in extraction replica prepared from steel $\mathrm{A}$ after treated with water for $2 \mathrm{hrs}$.

時間が長くなるにしたがつて針状の炭化モリブデン $\left(\mathrm{Mo}_{2} \mathrm{C}\right)$ の形状はくずれ，水溶性は明らかであつた。

\section{2. 酸溶解法以外の方法}

炭化モリブデン $\left(\mathrm{Mo}_{2} \mathrm{C}\right)$ を鋼から抽出分離する方法とし て㛟討したクエン酸ナトリウム系電解液定電位電解法, ア セチルアセトン系電解液定電位電解法, アセチルアセトン 直接溶解法 ${ }^{(9)}$, よ5素ーブチルアルコール溶解法, 塩化鉄一 ブチルアルコール溶解法の検討結果の要点のみを述べる.

\footnotetext{
(1) クエン酸ナトリウム系電解液定電位 電解法
}

電解液を $5 \%$ クエン酸 ナトリウム $-1.2 \%$ 臭化カリウム ( $\mathrm{pH}:$ 1〜 7) とし, 電解槽をKoch-Sundermann 式縦型電解 槽として検討した．この方法はマトリックスの脱落混入が あること, セメンタイトが混入し，七メンタイト中のモリ ブデン固溶量を補正する必要があること, 炭化モリブデン はこの電解液に溶解する扣それがあることの理由で採用し なかつた。

\section{（2）アセチルアセトン系電解液定電位 電解法}

1 の結果から炭化モリブデン $\left(\mathrm{Mo}_{2} \mathrm{C}\right)$ を溶解するおとれ の少ないアセチルアセトンを電解液として用いることに し, $10 \%$ 塩化鉄-5\%塩化曲鉛-アセチルアセトン電解液の 使用を検討した。この電解法では (1) の問題点は注ぼ解決 されたがモリブデンとしての炭化モリブデン $\left(\mathrm{Mo}_{2} \mathrm{C}\right)$ の定 量值は $0.74 \sim 0.91 \%$ で後述 (3) のりん酸室温溶解法に比較 して低值であり，かつ分析精度が不良であつた。

\section{(3)アセチルアセトン直接溶解法 ${ }^{(9)}$}

アセチルアセトンで鋼を直接溶解し，炭化モリブデン $\left(\mathrm{Mo}_{2} \mathrm{C}\right)$ を抽出分離することを試みた。溶解温度は $120^{\circ} \mathrm{C}$ としたが地鉄溶解に約 30 時間を要し，モリブデンとして の炭化モリブデン $\left(\mathrm{Mo}_{2} \mathrm{C}\right)$ の定量值は $0.43 \sim 0.57 \%$ と低值 であり，かつ抽出分離残さはアセチルアセトン鉄の皮膜で 扣执われ，洗浄に長時間を要した。

\section{(4) よう素 (または塩化鉄) -ブチルアルコ 一ル溶解法}

鋼から抽出分離した炭化モリブデン $\left(\mathrm{Mo}_{2} \mathrm{C}\right)$ は $\mathrm{n}$-ブチル アルコールにはほとんど溶解しないのでよう素ーブチルア ルコール溶解法および塩化第二鉄 - ブチルアルコール溶解 法を検討した。しかし，モリブデンとしての炭化モリブデ ン $\left(\mathrm{Mo}_{2} \mathrm{C}\right)$ 定量值は前者で $0.24 \sim 0.38 \%$, 後者で 0.09 $0.17 \%$ と著しく低值であつた。

\section{3. 酸 溶 解 法}

\section{（1）溶解酸の選定}

溶解酸として塩酸, 硫酸, りん酸, 渦塩素酸, 酢酸を比 較検討した。すなわち, 試料 A $0.1 \mathrm{~g}$ をそれぞれ, ビーカ 一(容量 $100 \mathrm{~mL}$ ) にはかりとり, 酸 $50 \mathrm{~mL}$ を加えたのち, 室温で静置または水浴中で $90^{\circ} \mathrm{C}$ に加熱して溶解し, 地鉄 の溶解を磁石を朋いて確認したのち, 抽出分離残さをミリ ポアフィルター $(100 \mathrm{~m} \mu)$ で吸引ろ過して捕集し，モリブ デンを定量した、結果を Table 2 に示す. Table 2 の結果 によればモリブデン定量值は加熱溶解法でも室温溶解法で もりん酸を用いた場合がもつとも高值であつた. また室温 溶解法に沶ける地鉄溶解所要時間でもりん酸を用いた場合 がもつとも早かつた、以上から著者らはりん酸を溶解酸と して選定した。な敃，りん酸のつぎには硫酸が上いと思わ れるが塩酸の使用は望ましくない。

\section{（2）りん酸溶解法における酸濃度の選定}

りん酸濃度を選定する検討を行なつた。すなわち，試料 
$\mathrm{A}$ と B の各 $0.1 \mathrm{~g}$ をビーカー (容量 $100 \mathrm{~mL}$ ) とはかりとり, 1〜44 N のりん酸 $50 \mathrm{~mL}$ を加えたのち，(1) の実験と同様

Table 2 Extraction of molybdenum carbide $\left(\mathrm{Mo}_{2} \mathrm{C}\right)$ from steel A with acids.

\begin{tabular}{|c|c|c|c|}
\hline \multirow{2}{*}{ Acid } & \multirow{2}{*}{$\frac{\begin{array}{c}\text { Heating method } \\
\left(90^{\circ} \mathrm{C}\right)\end{array}}{\begin{array}{l}\text { Mo extracted } \\
(\% \text { in steel })\end{array}}$} & \multicolumn{2}{|c|}{ Room temp. method } \\
\hline & & $\begin{array}{l}\text { Mo extracted } \\
(\% \text { in steel })\end{array}$ & $\begin{array}{l}\text { Extraction } \\
\text { time (hr) }\end{array}$ \\
\hline $6 \mathrm{~N} \mathrm{HCl}$ & 0.74 & 0.06 & 80 \\
\hline $12 \mathrm{~N} \mathrm{H}_{2} \mathrm{SO}_{4}$ & & 0.84 & 45 \\
\hline $6 \mathrm{~N} \mathrm{H}_{2} \mathrm{SO}_{4}^{4}$ & 0.85 & 0.63 & 15 \\
\hline $30 . \mathrm{N} \mathrm{H}_{3}^{2} \mathrm{PO}_{4}^{2}$ & & 0.95 & 15 \\
\hline $6 \mathrm{~N} \mathrm{H}_{3} \mathrm{PO}_{4}$ & 0.90 & 0.86 & 15 \\
\hline $3 \mathrm{~N} \mathrm{H}_{3} \mathrm{PO}_{4}$ & 0.86 & 一 & 一 \\
\hline $\begin{array}{l}6 \mathrm{~N} \mathrm{HClO}_{4} \\
3 \mathrm{~N} \mathrm{HClO}\end{array}$ & 0.05 & - & 一 \\
\hline $6 \mathrm{~N}$ & & & \\
\hline $\begin{array}{l}\mathrm{CH}_{3} \mathrm{COOH} \\
3 \mathrm{~N}\end{array}$ & 0.52 & 0.39 & 80 \\
\hline $\mathrm{CH}_{3} \mathrm{COOH}$ & 0.38 & — & - \\
\hline
\end{tabular}

の影響は注とんど無視しうることがわかつた。しかし，6 $\mathrm{N}$ りん酸を用いた場合には地鉄溶解直後も低值であるが抽

Table 4 Effect of standing time after dissolution of steel $\mathrm{A}$ on extraction of molybdenum carbide $\left(\mathrm{Mo}_{2} \mathrm{C}\right)$.

\begin{tabular}{|c|c|c|c|}
\hline $\begin{array}{l}\text { Standing } \\
\text { time } \\
\text { (hr) }\end{array}$ & $\begin{array}{l}\text { Mo extracted } \\
\text { with } \\
30 \mathrm{~N} \mathrm{H}_{3} \mathrm{PO}_{4} \text { at } \\
\text { room temp. } \\
\text { (\% in steel) }\end{array}$ & $\begin{array}{c}\text { Mo extracted } \\
\text { with } \\
30 \mathrm{~N} \mathrm{H}_{3} \mathrm{PO}_{4} \\
\text { by heating } \\
\left(90^{\circ} \mathrm{C}\right), \\
(\% \text { in steel })\end{array}$ & $\begin{array}{c}\text { Mo extracted } \\
\text { with } \\
6 \mathrm{~N} \mathrm{H}_{3} \mathrm{P}_{4} \\
\text { by heating } \\
\left(90^{\circ} \mathrm{C}\right) \\
(\% \text { in steel })\end{array}$ \\
\hline $\begin{array}{r}0 \\
1 \\
5 \\
9 \\
21 \\
24 \\
28 \\
48 \\
72 \\
98\end{array}$ & $\begin{array}{c}0.94 \\
\bar{Z} \\
0 . \overline{94} \\
0.93 \\
\overline{0} \\
\overline{0.94} \\
0.94 \\
0.95\end{array}$ & $\begin{array}{l}0.92 \\
0.92 \\
0.91 \\
\overline{-} \\
\overline{0.92} \\
\overline{0.92} \\
0.91 \\
-\end{array}$ & $\begin{array}{l}0.88 \\
0.85 \\
0.86 \\
\overline{\bar{Z}} \\
0 . \overline{82} \\
\overline{-} \\
\overline{0.55} \\
-\end{array}$ \\
\hline
\end{tabular}

Table 3 Effect of phosphoric acid concentration on extraction of molybdenum carbide $\left(\mathrm{Mo}_{2} \mathrm{C}\right)$ from steel $\mathrm{A}$ and $\mathrm{B}$.

\begin{tabular}{|c|c|c|c|c|c|c|c|c|}
\hline \multirow{3}{*}{$\begin{array}{l}\text { Concn. } \\
\text { of } \\
\text { phosphoric } \\
\text { acid }(\mathrm{N})\end{array}$} & \multicolumn{4}{|c|}{ Steel A } & \multicolumn{4}{|c|}{ Steel B } \\
\hline & \multicolumn{2}{|c|}{ Heating method $\left(90^{\circ} \mathrm{C}\right)$} & \multicolumn{2}{|c|}{ Room temp. method } & \multicolumn{2}{|c|}{ Heating method $\left(90^{\circ} \mathrm{C}\right)$} & \multicolumn{2}{|c|}{ Room temp.method } \\
\hline & $\begin{array}{l}\text { Mo extracted } \\
(\% \text { in steel) }\end{array}$ & $\begin{array}{l}\text { Extraction } \\
\text { time (hr) }\end{array}$ & $\begin{array}{l}\text { Mo extracted } \\
(\% \text { in steel })\end{array}$ & $\begin{array}{l}\text { Extraction } \\
\text { time (hr) }\end{array}$ & $\begin{array}{l}\text { Mo extracted } \\
(\% \text { in steel })\end{array}$ & $\begin{array}{l}\text { Extraction } \\
\text { time (hr) }\end{array}$ & $\begin{array}{l}\text { Mo extracted } \\
(\% \text { in steel })\end{array}$ & $\begin{array}{l}\text { Extraction } \\
\text { time }(\mathrm{hr})\end{array}$ \\
\hline $\begin{array}{l}44 \\
38 \\
30 \\
26 \\
18\end{array}$ & $\begin{array}{l}0.75 \\
0.88 \\
0.91 \\
0.89 \\
0.87 \\
0.88\end{array}$ & $\begin{array}{l}0.5 \\
0.4 \\
0.3 \\
0.3 \\
0.3\end{array}$ & $\begin{array}{l}0.93 \\
0.95 \\
0.94 \\
0.95 \\
0.94\end{array}$ & $\begin{array}{l}26 \\
18 \\
15 \\
15 \\
15\end{array}$ & $\begin{array}{l}0.28 \\
0.28 \\
0.28 \\
0.27 \\
0.25\end{array}$ & $\begin{array}{l}1.1 \\
1.1 \\
0.9 \\
0.9 \\
0.9\end{array}$ & $\begin{array}{l}-\overline{0.28} \\
0.28 \\
0.28 \\
0.26\end{array}$ & $\begin{array}{r}>170 \\
40 \\
40 \\
27 \\
40\end{array}$ \\
\hline $\begin{array}{r}6 \\
1\end{array}$ & $\begin{array}{l}0.80 \\
0.85 \\
0.06\end{array}$ & $\begin{array}{l}0.3 \\
3\end{array}$ & $\begin{array}{l}0 . \overline{85} \\
0.10\end{array}$ & $\begin{array}{l}\overline{26} \\
53\end{array}$ & $\begin{array}{l}0 . \overline{16} \\
0.01\end{array}$ & $\begin{array}{l}1 . \overline{1.5} \\
4.5\end{array}$ & 0.07 & $\begin{array}{r}1 \overline{37} \\
>\end{array}$ \\
\hline
\end{tabular}

に加熱溶解, 室温溶解を行なつて抽出分離残さ中のモリブ デンを定量した。結果を Table 3 に示す. Table 3 によれ ば加熱溶解でも室温溶解でもりん酸濃度は $30 \mathrm{~N}$ 付近が最 適であることがわかつた。

\section{(3) りん酸溶解法における地鉄溶解後の 放置時間の影響}

$30 \mathrm{~N}$ りん酸室温溶解法によつて抽出分離した炭化モり ブデン $\left(\mathrm{Mo}_{2} \mathrm{C}\right)$ の同溶液中に括ける安定性を調べる目的で, 地鉄の溶解を確認したのちひきつづいて同溶液中に一定時 間放置した。すなわち，試料 A $0.1 \mathrm{~g}$ をビーカー(容量 100 $\mathrm{mL}$ ) にはかりとり，30 N りん酸 $50 \mathrm{~mL}$ を加えて(1) の実験 と同様に加熱溶解, 室温溶解を行なつて地鉄の溶解を確認 したのち, 加熱溶解の場合には室温まで泠却したのち, 室 温溶解の場合にはそのまま一定時間放置した。(1)の実験 と同様に抽出分離残さをろ別し，モリブデン量を定量し た. 結果を Table 4 亿示す. な拈, Table 4 亿は参考とし て $6 \mathrm{~N}$ りん酸によつて加熱溶解し, 同溶液中に放置した結 果を併記した。 Table 4 の結果によれば $30 \mathrm{~N}$ りん酸を用 いる場合には加熱溶解, 室温溶解のいずれの方法で抽出分 離した残さでも同溶液中では安定で地鉄溶解後の放置時間
出分離残さむ $6 \mathrm{~N} り$ ん酸中では不安定でしだいに低值とな ることがわかつた。

\section{(4) りん酸溶解法における溶解温度の選定}

$30 \mathrm{~N}$ りん酸溶解法に括ける溶解温度を定める検討を行 なつた。すなわち，試料 $\mathrm{A}$ と Bの $0.1 \mathrm{~g}$ をそれぞれ三角フ ラスコ(容量 $100 \mathrm{~mL}$ ) にはかりとり, $30 \mathrm{~N} り$ ん酸 $50 \mathrm{~mL}$ 加えたのち, 水浴を用いて各温度で溶解し，(1)の実験と同 様にモリブデン量を定量した。結果をTable 5 亿示す。

Table 5 Effect of temperature on extraction of molybdenum carbide $\left(\mathrm{Mo}_{2} \mathrm{C}\right)$ from steel $\mathrm{A}$ and $\mathrm{B}$ with $30 \mathrm{~N}$ phosphoric acid.

\begin{tabular}{|c|c|c|c|c|}
\hline \multirow[b]{2}{*}{$\begin{array}{c}\text { Temp. } \\
\left({ }^{\circ} \mathrm{C}\right)\end{array}$} & \multicolumn{2}{|c|}{ Steel A } & \multicolumn{2}{|c|}{ Steel B } \\
\hline & $\begin{array}{c}\text { Mo } \\
\text { extracted } \\
(\% \text { in } \\
\text { steel })\end{array}$ & $\begin{array}{c}\text { Extraction } \\
\text { time (hr) }\end{array}$ & $\begin{array}{c}\text { Mo } \\
\text { extracted } \\
(\% \text { in } \\
\text { steel })\end{array}$ & $\begin{array}{l}\text { Extraction } \\
\text { time (hr) }\end{array}$ \\
\hline $\begin{array}{l}20 \\
40 \\
60 \\
75 \\
90\end{array}$ & $\begin{array}{l}0.95 \\
0.94 \\
0.94 \\
0.93 \\
0.92\end{array}$ & $\begin{array}{c}15 \\
2 \\
0.7 \\
0.5 \\
0.3\end{array}$ & $\begin{array}{l}0.28 \\
0.27 \\
0.28 \\
0.27 \\
0.28\end{array}$ & $\begin{array}{l}25 \\
8 \\
2.7 \\
1.7 \\
0.7\end{array}$ \\
\hline
\end{tabular}


Table 5 の結果に上れば試料Aでは溶解温度が上昇するに つれて低值となつたが試料 B ではほとんど変わらなかつ た。以上の結果から安全をみて室温で溶解することにし た.

\section{(5)りん酸溶解法における抽出分離残さ の捕集法}

$30 \mathrm{~N}$ り 几酸室温溶解法によつて抽出分離した残さの捕 集法を検討した。すなわち，試料 Aを(1) の実験と同様に $30 \mathrm{~N}$ ク儿酸室温溶解法で溶解し，地鉄の溶解を確認した のち，吸引ろ過法や遠心分離法で抽出分離残さを捕集し， モリブデン量を定量して比較した。吸引ろ過には平均目孔 径 $100,220,300 \mathrm{~m} \mu$ のミリポアフィルター, 万紙 5 種Cを ミリポアフィルター用吸引ろ過器につけて用いた，遠心分 離は $4000 \mathrm{rpm}, 5$ 分間を 3 回繰り返光した．抽出分離残さ の洗浄は $30 \mathrm{~N}$ りん酸で行なつた。結果によればミリポア フィルター 3 種の場合にはいずれもモリブデン量 $0.94 \%$, 万紙 5 種 C 1 枚の場合には $0.10 \%$,同 2 枚の場合には 0.60 $\%$, 遠心分離の場合には $0.67 \%$ の值が得られた。 以上か らミリポアフィルターによる捕集を行ならことにしたが， ろ過所要時間はミリポアフィルター $300 \mathrm{~m} \mu$ で約 10 分間, $220 \mathrm{~m} \mu$ で約 20 分間, $100 \mathrm{~m} \mu$ で約 2 時間であつたのでミ リポアフィルター $220 \mathrm{~m} \mu$ を使用することにした。

\section{(6) その他}

抽出分離残さ中にりん酸が共存すると電顕観察が困難な ので $6 \mathrm{~N}$ 硫酸に上る洗浄を検討した。試料 $\mathrm{A} 0.1 \mathrm{~g}$ から抽 出分離した残さ中のモリブデン量は $6 \mathrm{~N}$ 硫酸 $50 \mathrm{~mL}$ を 3 回にわけて 4 分間洗浄した場合に $0.90 \%$ で，多少低值と なつたが他に良法がなかつたので採用することにした。 上 記にしたがつて抽出分離残さの電顕観察を行なつたとこ 万, 抽出分離残さ中に径 400 1000 ̊ の非結晶性粒状物質 が混入していることがわかつた。この粒状物質はあらかじ めろ過したりん酸を用いた場合にはほとんど認められない こと，りん酸をうすめて直接観察した場合にも認められる ことからりん酸中の不純物と思われる。この不純物はIII 1 の (6) に示した各社のりん酸中にいずれも認められた。 りん酸はろ過して用いてもろ過せずに用いても炭化モりブ デンの定量值には影響しないことを確愁した，以上から電 顕観察を行なら場合に限り, あらかじめミリポアフィルタ 一 $(220 \mathrm{~m} \mu)$ でろ過したりん酸を用い，抽出分離残さは $6 \mathrm{~N}$ 硫酸 $50 \mathrm{~mL}$ で 3 回に分けて洗浄することにした.

\section{IV. 定量法}

以上から鋼中炭化モリブデン $\left(\mathrm{Mo}_{2} \mathrm{C}\right)$ 抽出分離定量法と して $30 \mathrm{~N}$ り 几酸室温溶解法を選定し, その抽出分離操作, モリブデン定量操作をつぎのように定めた。

\section{(1) 炭化モリブデン $\left(\mathrm{Mo}_{2} \mathrm{C}\right)$ 抽出分離操作}

切削試料 $0.100 \mathrm{~g}$ をビーカー(容量 $100 \mathrm{~mL}$ ) にはかりと り， $30 \mathrm{~N}$ りん酸 $50 \mathrm{~mL}$ を加えて時計ざらで扔执い，室温
で静置して溶解する．地鉄の溶解を磁石を用いて確認した のち, ミリポアフィルター $(220 \mathrm{~m} \mu)$ とミリポアフィルタ 一用ろ過器で吸引ろ過し, 抽出分離残さを $30 \mathrm{~N}$ りん酸約 $50 \mathrm{~mL}$ を数回に分けて洗浄する.

\section{(2) 抽出分離残さ中モリブデン定量操作†}

抽出分離残さをミリポアフィルターごと，ビーカー（容 量 $100 \mathrm{~mL}$ ) 移し, 万過器に付着した残さを小片のろ紙 5

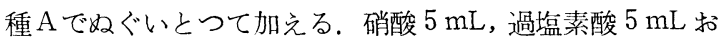
上び硫酸 $5 \mathrm{~mL}$ を加えて加熱分解し，加熱をつづけて硫酸 白煙処理を行なう。室温まで放冷したのち水を加えて 200 $\mathrm{mL}$ のメスフラスコに移し， 標線まで水を加えて上く振り 混ぜる。モリブデン $50 \mu \mathrm{g}$ 以下を含むよ5に一定量を分液 万丂 と(容量 $250 \mathrm{~mL}$ ) に分取し, 鉄溶液 $(5 \mathrm{mg} \mathrm{Fe}$

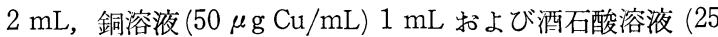
\%) $10 \mathrm{~mL}$ を加えて振り混ぜる. 硫酸 $(1+1) 20 \mathrm{~mL}$ と水で 液量を約 $90 \mathrm{~mL}$ としたのち室温まで冷却する。チオシア ン酸カリウム溶液 (25\%) $10 \mathrm{~mL}$ を加兄て振り混ぜる. 塩化 第一寸ず塩酸溶液( $25 \%) 9 \mathrm{~mL}$ を加えて振り混ぜたのち MIBK $25 \mathrm{~mL}$ を正しく加えて約 90 秒間激しく振り混ぜる. 静置し，下層を除いたのち，しゆう酸 $2 \%$ を含む $1.2 \mathrm{~N}$ 塩 酸 $50 \mathrm{~mL}$ で約 1 分間振と5して洗浄する.つぎに $2.4 \mathrm{~N}$ 塩 酸 $50 \mathrm{~mL}$ で約 1 分間振と 5 して洗浄する。 MIBK 層の一 部を乾燥ろ紙でろ 過しながら光度計の吸収七ルにとり， MIBK を対照液としてろ光板 S 47 飞括ける吸光度を測定 する，あらかじめ作成してある検量線を用いてモリブデン 量を定量するけり。

\section{V. 定量例}

N の定量法にしたがつて試料 A， B ，Cを独立 10 回分析

Table 6 Precision of the proposed method (Mo as $\mathrm{Mo}_{2} \mathrm{C}, \%$ in steel).

\begin{tabular}{r|c|c|c}
\hline No. & Steel A & Steel B & Steel C \\
\hline 1 & 0.96 & 0.28 & 0.70 \\
2 & 0.94 & 0.27 & 0.70 \\
3 & 0.95 & 0.28 & 0.70 \\
4 & 0.94 & 0.28 & 0.71 \\
5 & 0.93 & 0.27 & 0.71 \\
6 & 0.94 & 0.28 & 0.71 \\
7 & 0.94 & 0.27 & 0.70 \\
8 & 0.96 & 0.28 & 0.71 \\
9 & 0.94 & 0.27 & 0.71 \\
10 & 0.94 & 0.28 & 0.71 \\
\hline$\overline{\mathrm{X}}$ & 0.944 & 0.276 & 0.706 \\
\hline $\mathrm{R}$ & 0.03 & 0.01 & 0.01 \\
\hline$\sqrt{\mathrm{V}}$ & 0.0097 & 0.0052 & 0.0052 \\
\hline $\mathrm{CV}(\%)$ & 1.0 & 1.9 & 0.7 \\
\hline
\end{tabular}

$†$ MIBK 抽出時淿水層に共存するりん酸 $2 \mathrm{~mL}$ まて は影響しない。

†† モリブデン量から炭化モリブデン $\left(\mathrm{MO}_{2} \mathrm{C}\right)$ 量を算出 するには次式による。

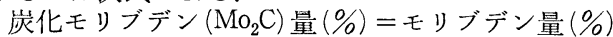
$\times 1.063$ 
して分析精度を算出し, 同時に抽出分離残さの電顕観察,

X線回折怙よび分析所要洔間の算出を行なつた，Table 6

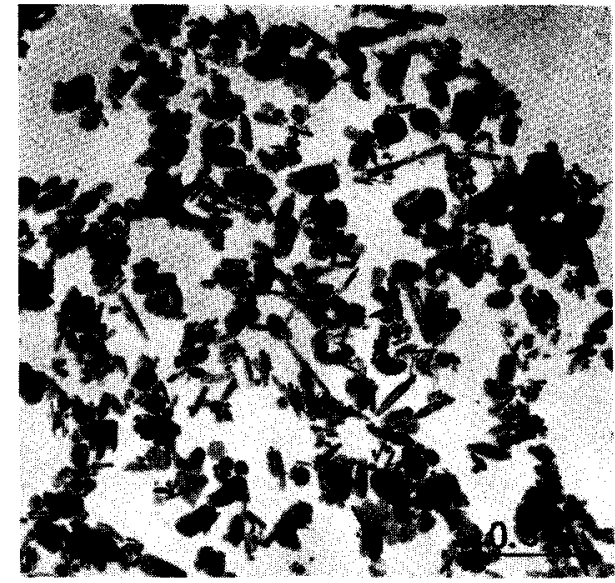

Photo. 5 Electron micrograph of the residue extracted from steel A with $30 \mathrm{~N}$ filtrated phosphoric acid and washed by $6 \mathrm{~N}$ sulphuric acid.

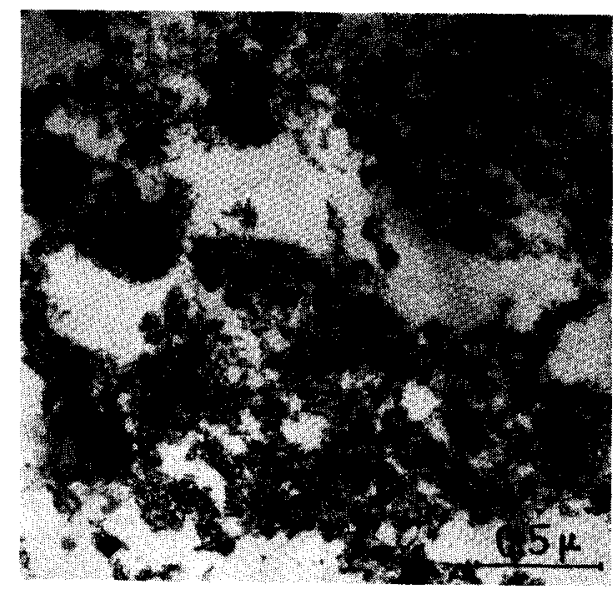

Photo.6 Electron micrograph of the residue extracted from steel $\mathrm{C}$ with $30 \mathrm{~N}$ filtrated phosphoric acid and washed by $6 \mathrm{~N}$ sulphuric acid.

に分析精度を算出した結果を，Photo.5，6亿電顕観察結 果の例を示吉，分析所要時間は抽出分離操作 $15 \sim 25$ 持間，
抽出分離残さ中モりブデン定量操作約 1 時間であつた。 な 拉，上就三試料の抽出分離残さのX線回折結果はいずれる 炭化モリブデン $\left(\mathrm{MO}_{2} \mathrm{C}\right)$ のみで他の化合物は検出されなか つた. Table 6 によ礼ば本法の分析精度は良好で通常の元 素分析の分析精度と大差ない結果であつた。な拈，抽出分 湤残さの発光分光分析による定性分析結果ではモリブデ ン，りん以外に鉄が検出されたので三試料の抽出分離残さ 中の鉄をニトロソR塩吸光光度法で定量したがいずれの試 料です $0.01 \%$ 以下であつた，Photo. 5 から抽出分離した 針状の炭化モりブデン $\left(\mathrm{Mo}_{2} \mathrm{C}\right)$ の長さは $500 \sim 2500 \AA$, 球状

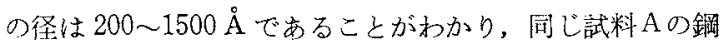
中抽计レプリカ電影観察結喿でする Photo.1, 2 と此較す ると同じ形状で同じ大きさの炭化モりブデン $\left(\mathrm{Mo}_{2} \mathrm{C}\right)$ が抽 计分離されていることがわかつた。

\section{VI. 結 諭}

（1）鋼中析出物介在物分析法の研究の一つとして鎆中炭 化モリブデン $\left(\mathrm{Mo}_{2} \mathrm{C}\right)$ の抽出分離定量法を検討した。すなお ち， $650^{\circ} \sim 750^{\circ} \mathrm{C}$ に焼もどした Fe-Mo-C 系試験溶解鋼を 刘象としてクエン酸ナトリウム系電解液定電位電解法, ア セチルアセトン系電解液定電位電解法,アセチルアセトン 直接溶解法，上5素ーブチルアルコール溶解法，塩化鉄-ブ チルアルコール溶解法, 酸溶解法を比較檢討した結果, 新

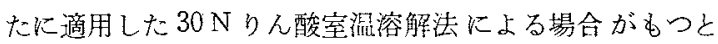
も高值で离り，かつ分析精度も良好であることがかかつ た.

(2) 鋼から抽出分離した炭化モリブデン $\left(\mathrm{Mo}_{2} \mathrm{C}\right)$ は化学 的に不安定であり，水にすら溶解する性質があつた。

(3) 甽㰾試料を $30 \mathrm{~N}$ り九酸で空温で溶解し：ミリポア フィルターて吸引ら別後，同溶液で洗浄し，抽出分離残さ 中のモリブデン量をMIBK 抽出チオンアン酸缊吸光光度法 で起量する。

（4）本法によれば鋼中のモりブデンとして0.02 1\%の 荻化モリブデン $\left(\mathrm{Mo}_{2} \mathrm{C}\right)$ を，抽出分離操作 $15 \sim 25$ 時間，抽 出分離残さ中モりブデン定量操作約 1 時間で定量すること ができた。 